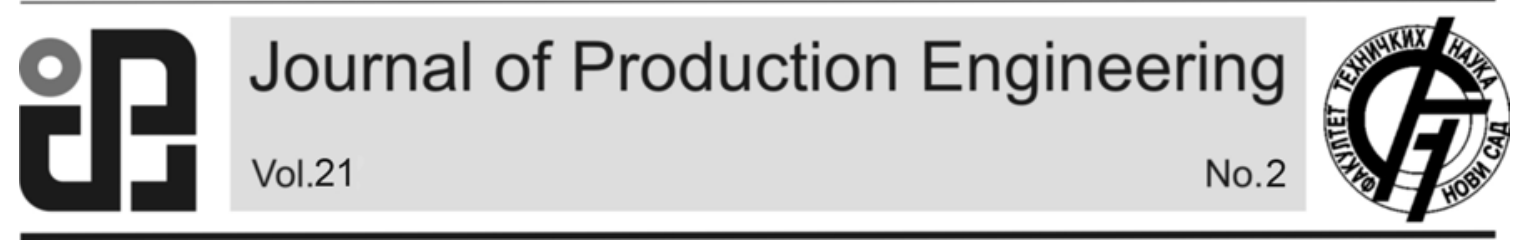

JPE (2018) Vol.21 (2)

Karić, S., Nasić, E., Pjanić, M.

Original Scientific Paper

\title{
INFLUENCE OF ADITTIONAL MASS ON THE CANTILEVER BEAM TO CARACTERISTICS BENDED DAMPING VIBRATION
}

\author{
Received: 30 September 2017 / Accepted: 25 April 2018
}

\begin{abstract}
In this paper a damping rate analysis was performed on the cantilever beam and loaded with an additional mass at the free end. The experimentally obtained results for bending damping vibration of the cantilever have been analyzed. The analysis gives the dependence of the damping factor, measured as the relation of the two adjacent amplitudes, from the moment of inertia, all in a non-dimensional form. It was found that there is an influence of additional mass on the internal damping coefficient for different inertia moment of the cantilever.
\end{abstract}

Key words: bending damping vibration, damping factor, internal damping coefficient, non-dimensional analysis.

Uticaj dodatne mase konzolnog nosača na karakteristike savojnih prigušenih vibracija. $U$ radu je rađena analiza stepena prigušenja kod konzolnog nosača sa i bez dodatne mase na slobodnom kraju. Analizirani su eksperimentalno dobijeni rezultati za savojne prigušene vibracije konzolnog nosača. Analiza daje zavisnosti faktora prigušenja od koeficijenta unutrašnjeg prigušenja u bezdimenzionalnom obliku. Utvrđeno je da postoji uticaj dodatne mase na koeficijent utrašnjeg prigušenja za različite momente inercije konzolnog nosača.

Ključne reči: savojne prigušene vibracije, faktor prigušenja, koeficijent unutrašnjeg prigušenja, bezdimenziona analiza.

\section{INTRODUCTION}

Damping is a phenomenon that, to some extent, accompanies vibration. Meanwhile, the mechanical energy in the material or system is scattered in the environment as an irreversible process.Inner damping in the material is most commonly caused as a result of internal reorganization in the structure of materials, such as molecular dislocation, and tension changes at the grain boundariesas a result of cyclic deformation.

For internal damping in the material, it can be said that to a large extent it depends on the material and geometry of the structure. Inner damping often can have a hysteresis character $[1,2,3,4]$. If the damping factor is relatively small, which is generally the case with internal damping in mechanical structures, the assumption about viscous damping is usually assumed by Voigt's setting [4, 5, 6, 7]. This means that the damping forces are proportional to the relative velocities of the material particles [8]. The damping model defined in this way is linear in nature.

The damping effect on the vibration of a particular mechanical system is reflected in the decrease in the amplitude of oscillation in the case of free damped vibrations. This influence is usually defined in the theory of vibration through an appropriate damping factor that shows the rate of decrease of the oscillation amplitude in function of the frequency or oscillation period [9]. In this paper, the bending damping vibration of the cantilever with and without additional mass at the free end is analyzed, in order to determine the mass impact on the internal friction coefficient $[10,11]$.

\section{DAMPING ANALYSIS}

\subsection{Damping factor}

Figure 1 shows an oscillatory single - degree - of freedom system, which consists of a mass, a spring and a dumper. An analysis of the influence parameters on the amplitude decreasing character can be performed on the given system.

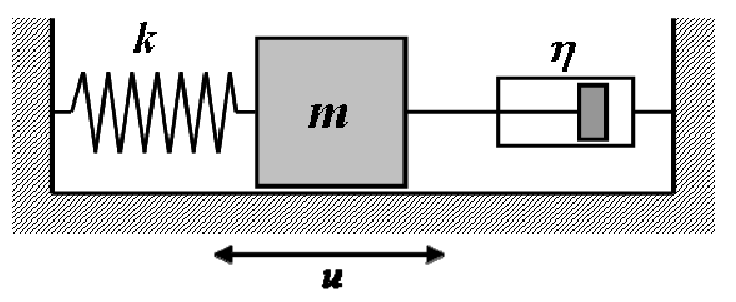

Fig 1. Schematic of a oscillatory single-degree-offreedom system

Considering the structural system shown in Figure 1, where $m$ is the mass of the moving object, $k$ the elastic stiffness coefficient and $\eta$ the viscous damping coefficient, the dynamic motion equation (1) of the system in Figure has the form:

$$
m \ddot{x}+\eta \dot{x}+k x=0
$$

Assuming the solution of equation (1) is in the form of an exponential function, it may be written as:

$$
x=A \cdot e^{-\zeta \omega_{0} t} \cos \left(\omega_{p} t+\alpha\right)
$$

where $\omega_{p}$ is the frequency of dumped vibration and $\alpha-\mathrm{a}$ phase shift that depends on the initial conditions. As it Figure 2 shows, the amplitude of damped systems in equation (2)decays exponentially over time. 


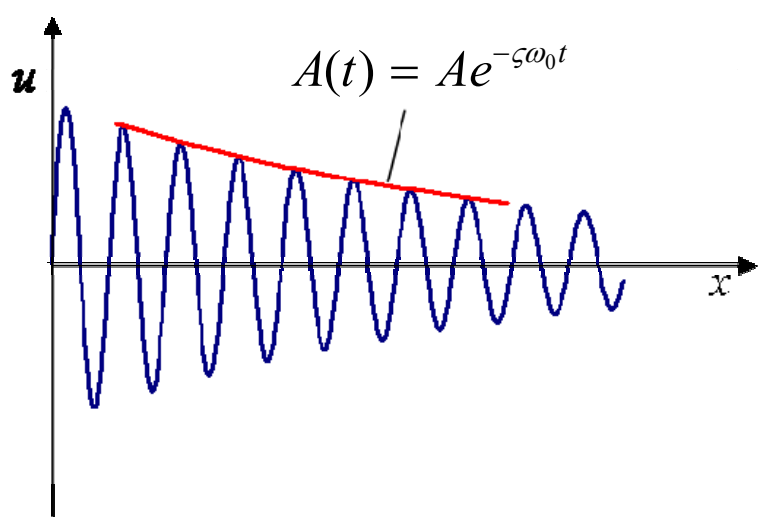

Fig. 2. The time response of an oscillatory singledegree - of - freedom system

Based on the equation (2), the ratio between two adjacent amplitudes at the beginning and end of one cycle can be written as:

$$
\frac{A_{n}}{A_{n+1}}=\frac{A e^{-\varsigma \omega_{0} t}}{A e^{-\varsigma \omega_{0}(t+T)}}=e^{\varsigma \omega_{0} T}
$$

Logarithmation of the expression (3) gives the logarithmic decrement of the attenuation

$$
\Lambda=\ln \frac{A_{n}}{A_{n+1}}
$$

and by dividing the logarithmic decrement with $\mathrm{T}$, the followingis obtained:

$$
\delta=\varsigma \omega_{0}=\frac{1}{T} \ln \frac{A_{n}}{A_{n+1}}
$$

where $\delta$ is the parameter indicating the free vibration damping measure, in the literature known as the damping factor [9].

As the basis for determining the degree of damping, the values of the measured time response of free damped vibrations are used.

Using this method, the degree of damping is determined by changing the oscillation amplitude in time.In this case, we are starting from the assumption that the damping in the structure, or system, can be treated as viscous. Amplitude of free damped vibrations in a single-degree-of- freedom system with viscous attenuation (Fig. 2), is changing in time according to the following exponential law :

$$
A(t)=A_{0} e^{-\delta t}
$$

where je $A_{0}$ is the initial amplitude of the oscillation, and $\delta$ is the attenuation factor.

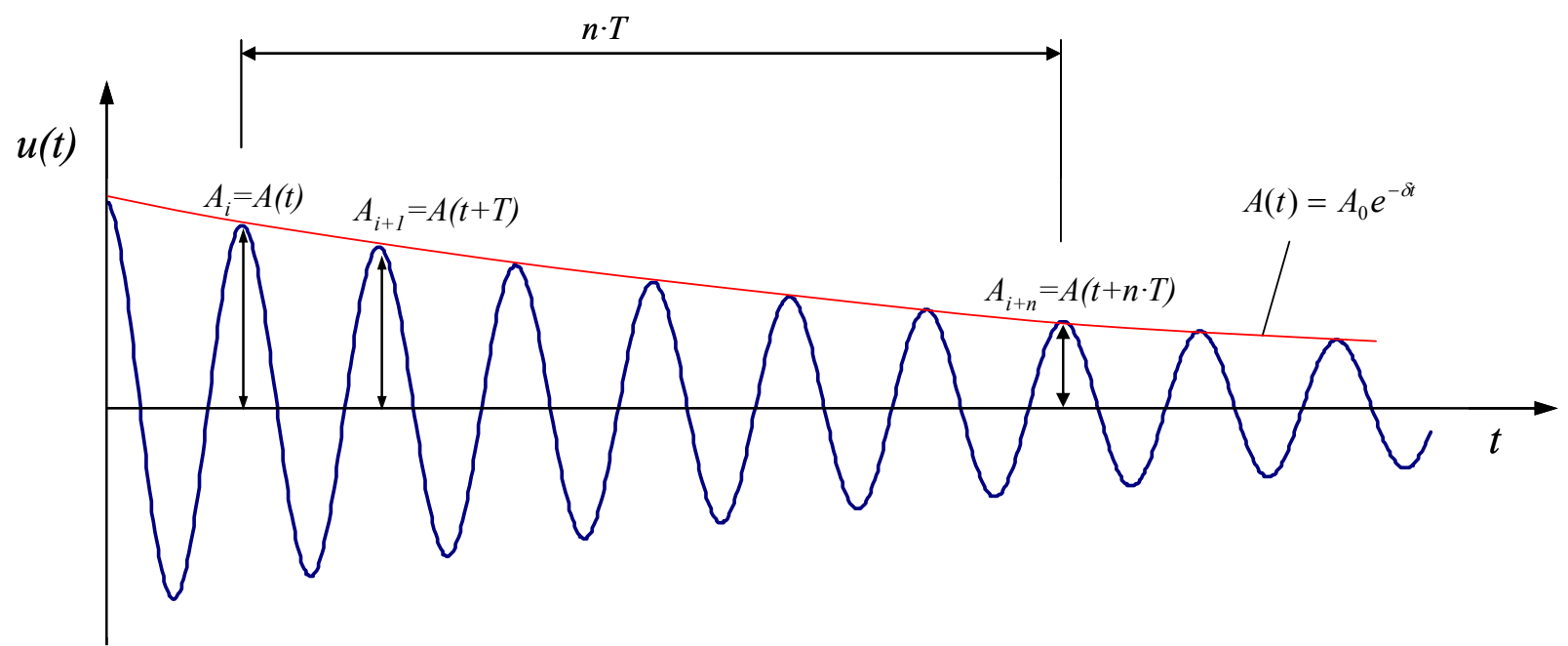

Fig. 3. 1Reduction of amplitude in viscous damped system with one degree of freedom

The value of the damping factor $\delta$ can be determined using the ratio of two adjacent amplitude $A_{i}$ at the beginning and $A_{i+l}$ at the end of the period (Figure 3 ).

$$
\frac{A_{i}}{A_{i+1}}=\frac{A_{0} e^{-\delta t}}{A_{0} e^{-\delta\left(t+T_{p}\right)}}=e^{\delta T_{p}}
$$

If the oscillation amplitude changes according to the exponential law given by the equation (6), the attenuation factor will have a constant value regardless of the choice of adjacent amplitudes $A_{i}$ and $A_{i+l}$ in the equation (7). The exponential curve, however, represents a theoretical assumption and the change of the oscillation amplitude in a real system can deviate more or less from the equation (6) since real attenuation changes over time. Consequently, it is recommended, instead of one period, to choose a longer interval of $n$ period and the attenuation factor can be calcuated based on the amplitude ratio $A_{i}$ and $A_{i+n}$ (Figure 3).

In this case, the damping factor is calculated as:

$$
\delta=\frac{1}{n \cdot T_{p}} \ln \frac{A_{i}}{A_{i+n}}
$$

In this paper, the attenuation factor values for the measured experimental results are calculated on the basis of the equation (8) where $n$ is the order of 100 . The damping factor can be written as:

$$
\bar{\delta}=\frac{1}{n \cdot \bar{T}_{p}} \ln \frac{A_{i}}{A_{i+n}}
$$

Where $\bar{T}_{p}$ is the period of free damped vibrations in a non-dimensional form given by expression: 


$$
\bar{T}_{p}=\frac{T_{p}}{L} \sqrt{\frac{E}{\rho}} .
$$

By combining the equations (8), (9) and (10), the relationship between the attenuation factor in the dimensional and the non-dimensional form is obtained

$$
\bar{\delta}=\delta \cdot L \sqrt{\frac{\rho}{E}},
$$

or,respectively:

$$
\bar{\delta}=\frac{1}{n \cdot \bar{T}_{p}} \ln \frac{A_{i}}{A_{i+1}}
$$

Dependencies are represented in a non-dimensional form (indicated by the line above the symbol). The nondimensional damping factor and the oscillation period, as well as the non-dimensional moment of inertia, provide a simpler analysis of the required dependencies. Measurements on cantilevers of certain thickness and different lengths, give inertia moments in a nondimensional form independent of the cantilever width. [9].

\section{RESULTS ANALYSIS}

The measurements were made on inox cantilevers of different dimensions with and without additional mass at the free end. The measurement sample scheme and the metering method using the metering strips are shown in Figure 4.

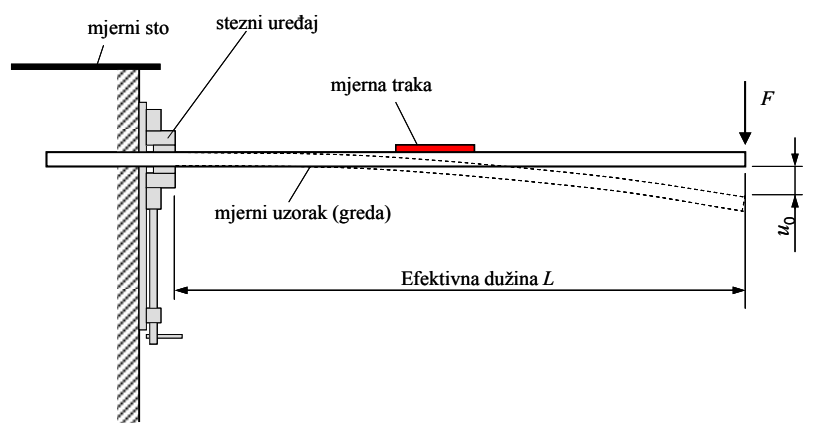

Fig. 4. Schematic of the measuring specimen, positioning of the measuring tape and the stimulus

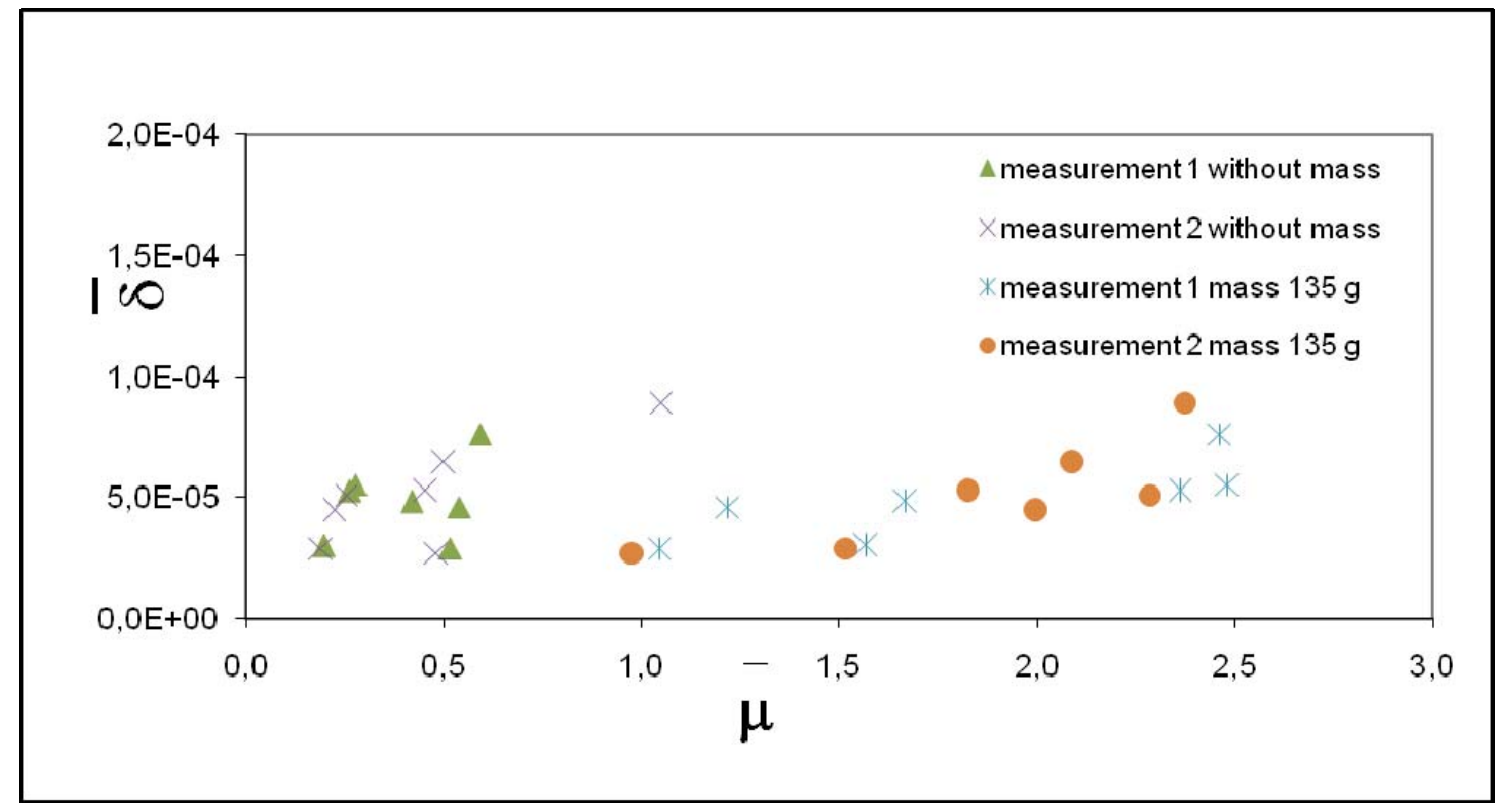

Fig. 5. Dependence of the damping coefficient of internal damping with and without additional mass

In order to determine the internal damping on each sample, several measurements were made, with the effective length of the beam being varied. Thus, for each beam, vibrational behavior of the beam is measured for different values of the non-dimensional moment of inertia defined as:

$$
\bar{I}=\frac{I}{A L^{2}}=\frac{h^{2}}{12 L^{2}}
$$

where $L$ is the lenght and $h$ - thickness of the beam. The non-dimensional inertion moment, which, as seen from equation (13), depends only on the length and thickness but not on the beams width, is the main geometrical characteristic of the beam.In this way, the influence of the geometrical characteristics of the beam on internal damping is to be examined. Each measurement for a given beam length was repeated several times in order to determine the accuracy or sensitivity of the measurement.

Measured damping factors $\delta$ are used to determine the internal damping coefficient $\mu$ in the material in the case of free damped bending vibrations of the elastic structures. The internal damping coefficient was introduced as a parameter in the damping model in the material, assuming that the damping force, which occurs as a result of material deformation, is proportional to the local velocity deformation rate. In accordance with this hypothesis, the equilibrium of motion of the free damped bending vibrations of the Euler-Bernoulli beam in the non-dimensional form is given by equation [9]:

$$
\bar{I} \frac{\partial^{4} \bar{u}}{\partial \bar{x}^{4}}-\bar{\mu} \bar{I} \frac{\partial^{4} \bar{u}}{\partial \bar{x}^{3} \partial \bar{t}}+\frac{\partial^{2} \bar{u}}{\partial \bar{t}^{2}}=0
$$

The values of the internal damping coefficient $\mu$ are calculated by the inverse method $[10,11]$. The equation (14) was solved numerically by using the finite element 
method to reproduce the console response obtained experientially for different beam configurations and for the initial and boundary conditions.

Based on the results obtained in Figure 5, the loss of the internal damping coefficient results for the measurements carried out with the additional mass is visible. It is also possible to determine the value deviation of the non-dimensional friction coefficient in the case of an additional mass in comparison to the nonmass case.

\section{CONCLUSION}

Comparing the values of the internal damping coefficient $\mu$, obtained for the measurement of the banding vibrations of the different values of inertia moments in the inoculum cantilever, the following can be concluded:

- Measuring of the amplitude reduction in case of an unbarbed console, gives the internal damping coefficient whose value is in ranges from 0.25 to 0.59 . It can be said that the values are moving in a narrow range, and the changes are expected because the internal damping coefficient is expressed numerically, based on experimentally obtained damping factor values.

- Measuring of the amplitude reduction in the case of a loaded console with an additional mass at the free end, gives the internal damping coefficient value in range from 0.98 to 2.48 , which is obviously a deviation of the result compared to the unbalanced console and the range of values is very wide.

\section{REFERENCES}

[1] Cannon R. H., Schmitz, E: Precise Control of Flexible Manipulators, The International Journal Robot Research, pp. 841-861, 1983.
[2] Craig R. R., Kurdila A. J.: Fundamentals of Structural Dynamics, $2^{\text {nd }}$ Ed. John Wiley\&Sons, INC, New Jersey, 2006.

[3] Beards C. F.: Structural Vibrations Analisys and Damping, University of London, Arnold, 1996.

[4] Bratosin D., Sireteanu T., Hysteretic Damping Modelling Nonlinear Kelvin-Voigt model, Proceedings of the Romania Academy, Series A, Volume 3, Number 3/2002.

[5] Nakić I.: Optimal Damping of Vibrational Systems,Dissertation, University in Hagen, 2003.

[6] Marynowski K.: Non-linear Dynamic Analysis of an Axialy Moving Viscoelastic Beam, Theoretial and Applied Mechanics, 2002.

[7] Marynowski K.: Non-linear Dynamic Analysis of an Axialy Moving Viscoelastic Beam, Theoretial and Applied Mechanics, 2002.

[8] GulaevV. I., BaznovV. A., PopovS. L.: Prikladniezadačiteoriinelinejnihkolebanijmehaničes kihsistem, Moskva, 1989.

[9] Karić, S.: Istraživanje nelinearnog dinamičkog modela unutrašnjeg prigušenja kod vibrirajućih struktura, Doctoral thesis, Mašinski fakultet $\mathrm{u}$ Sarajevu, Sarajevo, 2013.

[10] Doleček V., Voloder A., Isić S.: Vibracije, Mašinski fakultet Univerziteta u Sarajevu, Sarajevo, 2009.

[11] Karic S., Voloder A., Bajric R., Kudumovic Dz.: Determination of the internal damping coefficient in an elastic clamping beam, Technics Technologies Education Management, 2012.

Authors:Assist. Professor Seniha Karić, M.Sc. Edis Nasić, M.Sc. Merisa Pjanić, University of Tuzla, Faculty of Mechanical Engineering, Univerzitetska 4, 75000 Tuzla, Bosnia and Herzegovina, Phone.: +38735320-920, Fax: +38735320-921.

E-mail: seniha.karic@untz.ba edis.nasic@untz.ba merisa.pjanic@untz.ba 